Brit. J. vener. Dis. (1966), 42, 119.

\title{
ASSESSMENT OF THE "LUOTEST" IN LATE SYPHILLIS*
}

\author{
BY
}

\author{
S. M. LAIRD AND A. L. THORBURN
}

VD Department, Royal Infirmary, Manchester

In 1908 Neisser applied the principles of the tuberculin test to the diagnosis of syphilis, using extracts of syphilitic organs (Neisser, 1911). Noguchi (1911) used a suspension of killed cultures of $T$. pallidum which he called "luetin". While the organ extracts proved more satisfactory than "luetin", the results were unreliable and this original "luetin" test was largely abandoned. Rottmann (1946), working in Vienna, using an extract of syphilitic rabbit testicle (luotest) as antigen, modified the original skin test by repeating the intradermal injection some 6 to 9 days after the initial injection. He claimed a higher proportion of positive skin tests with this "doubleinjection" technique. Although Rottmann's method is used enthusiastically by some neuropsychiatrists (e.g. Grillmayr, 1956), it has failed to gain any widespread adoption.

Csonka (1950) studied the performance of the "luotest" skin reaction in London in 155 patients, because he believed that if the reliability of the "luotest" skin reaction could be substantiated, the test would be of value:

(1) As an aid to diagnosis in active sero-negative late acquired or congenital syphilis;

(2) As an index of activity in sero-positive cases with or without clinically diagnosable lesions;

(3) To control the amount of treatment in patients with late syphilis where the "reagin" tests give little guidance.

The skin test was known to give negative reactions in patients with early syphilis, and Csonka (1950) found a weak reaction in only two of 33 such cases. The test was negative in 21 of 23 control cases drawn from a general medical ward and, in the two patients in whom the "luotest" reaction was positive, the Wassermann reaction (WR) was also subsequently found to be positive. In fourteen untreated cases of

* Received for publication June 28, 1965 active benign tertiary syphilis, the "luotest" reaction was positive in each one, and a close correlation with the Wassermann reaction was found in thirteen cases of cardiovascular syphilis. A positive skin test was found in fifteen of sixteen untreated cases of neurosyphilis but in only three of ten treated patients; a similar performance was obtained in 21 cases of late congenital syphilis.

\section{Present Study}

The treponema immobilization test (TPI) has brought a greater degree of accuracy to the diagnosis or exclusion of latent and late syphilis, particularly in those patients in whom the "reagin" tests have become negative, and it seemed of interest to study the "luotest" skin reaction in a group of patients in whom the diagnosis of syphilis was certain and in a control group of patients in whom all the evidence, including the TPI, ruled out this diagnosis. Rottman's modification of the original skin test seems open to the objection that a positive reaction obtained only after a second intradermal reaction may result from sensitization induced by the first; to be convincing we believe that the performance of the test should be judged after the use of a single intradermal injection. Csonka (1950) found that, of a total of 79 positive "luotests", twenty ( 24 per cent.) were positive only at the second testing.

"Luotest" is a sterile extract from rabbit syphilitic testes diluted with 0.5 per cent. phenol in normal saline; $0 \cdot 2 \mathrm{ml}$. was injected intradermally into the forearm. The patients were examined about $48 \mathrm{hrs}$. later; a positive result was recorded if a welldemarcated, round or oval, pink or red, patch over $25 \mathrm{~mm}$. in diameter was still present.

The syphilitic patients tested were selected from those attending the VD clinic at the Royal Infirmary, Manchester. In each of the forty patients selected, the TPI test was positive and there was clinical evidence of late acquired or congenital syphilis 
(see Table). The control group comprised forty patients in the psychiatric wards of Springfield Hospital, Manchester. Serum tests for syphilis, WR, Price's precipitation reaction (PPR), and the Reiter protein complement-fixation test (RPCFT), are carried out routinely in all patients admitted to these wards, but an additional blood test including the TPI was done in the forty control patients. A complete physical examination was also carried out.

\section{Results}

In all the forty control patients, physical examination and standard serological tests for syphilis (WR, PPR, and RPCFT) proved negative, but in one patient the TPI was reported to be positive. The "luotest" skin reaction was negative in 38 patients, including the one with a positive TPI test; the positive skin reaction in the two patients in whom the TPI was negative was not strongly positive. Only one test was made in each patient of this control group.

The results of the "luotest" skin reaction in the forty syphilitic patients are shown in the Table. The "luotest" was positive in thirteen patients at the first test, and the second test performed on 24 patients was positive in a further nine cases. Thus the reaction was positive in 32.5 per cent. after the first injection, and in sixteen ( 66.6 per cent.) of the 24 patients in whom two intradermal tests were carried out. The reaction was negative in 27 patients (67.5 per cent.) after one intradermal test, and in eight (33 per cent.) of 24 patients in whom two intradermal tests were made.

While the majority of the syphilitic patients had been treated adequately with penicillin before the "luotest" was carried out, the reaction was tested in thirteen patients before they had received more than ten weekly injections of long-acting penicillin (Nos. $51,876,179,740,1,477,475,886,23,1423,1395$, 885 , and 701). In these thirteen patients, the reaction to the first test was positive in only one (No. 885). A second intradermal test was positive in four and negative in the four others in which it was carried out.

\section{Summary and Conclusion}

The "luotest" has been carried out in forty patients with clinical and serological evidence of syphilis and in a further group of 39 patients in whom syphilis could be excluded. In addition to the "reagin" tests, the TPI was included in the serological examinations.

The "luotest" reaction was positive in two patients of the non-syphilitic group in whom only one intradermal test was carried out. In the syphilitic
TABLE

RESULTS IN FORTY SYPHILITIC PATIENTS

\begin{tabular}{|c|c|c|c|c|c|c|c|c|c|}
\hline \multirow{2}{*}{$\begin{array}{l}\text { Case } \\
\text { No. }\end{array}$} & \multirow{2}{*}{$\operatorname{Sex}$} & \multirow{2}{*}{$\begin{array}{c}\text { Age } \\
\text { (yrs) }\end{array}$} & \multirow{2}{*}{$\begin{array}{l}\text { Diag- } \\
\text { nosis }\end{array}$} & \multirow{2}{*}{ WR } & \multirow{2}{*}{ PPR } & \multirow{2}{*}{ RPCFT } & \multicolumn{2}{|c|}{ Luotest } & \multirow{2}{*}{$\begin{array}{l}\text { Cere- } \\
\text { bro- } \\
\text { spinal } \\
\text { Fluid }\end{array}$} \\
\hline & & & & & & & 1 & 2 & \\
\hline $\begin{array}{r}129 \\
75 \\
735 \\
894 \\
51 \\
1330\end{array}$ & $\begin{array}{l}\mathbf{M} \\
\mathbf{M} \\
\mathbf{M} \\
\mathbf{M} \\
\mathbf{M} \\
\mathbf{F}\end{array}$ & $\begin{array}{l}59 \\
52 \\
47 \\
38 \\
53 \\
40\end{array}$ & $\begin{array}{l}a \\
a \\
a \\
a \\
a \\
a\end{array}$ & $\begin{array}{l}\overline{+} \\
+ \\
+ \\
+ \\
+\end{array}$ & $\begin{array}{l}1 / \overline{2} \\
1 / 8 \\
\pm \\
+\end{array}$ & $\begin{array}{l}+ \\
+ \\
+ \\
+ \\
+ \\
-\end{array}$ & $\begin{array}{l}\bar{z} \\
\bar{z} \\
\bar{z} \\
\overline{-}\end{array}$ & $\begin{array}{c}\text { ND } \\
\text { ND } \\
+- \\
++ \\
++ \\
+\end{array}$ & $\begin{array}{c}\overline{+} \\
\overline{+} \\
+ \\
+ \\
\text { ND }\end{array}$ \\
\hline $\begin{array}{r}131 \\
1333\end{array}$ & $\begin{array}{l}\mathbf{M} \\
\mathbf{F}\end{array}$ & $\begin{array}{l}34 \\
46\end{array}$ & $\begin{array}{l}b \\
b\end{array}$ & + & $\begin{array}{l}1 / 2 \\
1 / 32\end{array}$ & $\stackrel{+}{+}$ & ++ & $\begin{array}{c}\text { ND } \\
++\end{array}$ & + \\
\hline $\begin{array}{r}159 \\
291 \\
231 \\
876 \\
1180 \\
179\end{array}$ & $\begin{array}{l}\mathbf{M} \\
\mathbf{M} \\
\mathbf{M} \\
\mathbf{M} \\
\mathbf{F} \\
\mathbf{M}\end{array}$ & $\begin{array}{l}44 \\
69 \\
32 \\
50 \\
53 \\
58\end{array}$ & $\begin{array}{l}c \\
c \\
c g \\
c \\
c \\
c\end{array}$ & $\begin{array}{l}+ \\
+ \\
+ \\
+ \\
+ \\
+\end{array}$ & $\begin{array}{l}1 / 4 \\
1 / 4 \\
1 / 4 \\
1 / 16 \\
1 / 16\end{array}$ & $\begin{array}{l}+ \\
+ \\
+ \\
+ \\
+ \\
+\end{array}$ & $\begin{array}{c}+\overline{+}+ \\
\underline{-} \\
++ \\
-\end{array}$ & $\begin{array}{c}\text { ND } \\
+++ \\
\text { ND } \\
\text { ND } \\
+++ \\
\text { ND }\end{array}$ & $\begin{array}{l}+ \\
+ \\
+ \\
+ \\
+ \\
+\end{array}$ \\
\hline $\begin{array}{r}1025 \\
740 \\
1\end{array}$ & $\begin{array}{l}\mathbf{F} \\
\mathbf{M} \\
\mathbf{M}\end{array}$ & $\begin{array}{l}37 \\
37 \\
35\end{array}$ & $\begin{array}{l}d \\
d \\
d\end{array}$ & $\begin{array}{l}+ \\
+ \\
+\end{array}$ & $\begin{array}{r}1 / 8 \\
+ \\
-\end{array}$ & \pm & $\overline{\bar{z}}$ & $\begin{array}{l}+ \pm+ \\
+\bar{t}+\end{array}$ & $\begin{array}{c}\text { ND } \\
\text { ND } \\
+\end{array}$ \\
\hline $\begin{array}{r}945 \\
27 \\
486 \\
400\end{array}$ & $\begin{array}{l}\mathbf{M} \\
\mathbf{M} \\
\mathbf{M} \\
\mathbf{M}\end{array}$ & $\begin{array}{l}39 \\
47 \\
49 \\
58\end{array}$ & $\begin{array}{l}e \\
e \\
e f \\
e f\end{array}$ & $\begin{array}{l} \pm \\
\pm \\
+\end{array}$ & $\begin{array}{l}1 / 16 \\
1 / 8 \\
1 / 128 \\
-\end{array}$ & $\begin{array}{l}+ \\
+ \\
+\end{array}$ & $\begin{array}{c}++ \\
\overline{-} \\
+\overline{+}+\end{array}$ & $\begin{array}{c}\text { ND } \\
++ \\
+\overline{+}+\end{array}$ & $\frac{+}{\mathrm{ND}}$ \\
\hline $\begin{array}{l}996 \\
180\end{array}$ & $\begin{array}{l}\mathbf{M} \\
\mathbf{M}\end{array}$ & $\begin{array}{l}38 \\
50\end{array}$ & $\begin{array}{l}h \\
h\end{array}$ & + & $\overline{-}$ & + & + & ND & + \\
\hline $\begin{array}{r}477 \\
10073\end{array}$ & $\begin{array}{l}\mathbf{M} \\
\mathbf{M}\end{array}$ & $\begin{array}{l}38 \\
48\end{array}$ & $\begin{array}{l}j \\
j\end{array}$ & $\stackrel{+}{+}$ & $\overline{-}$ & $\bar{t}$ & $+\overline{+}+$ & $\overline{\mathrm{ND}}$ & ND \\
\hline $\begin{array}{r}422 \\
475 \\
886 \\
23 \\
182 \\
750 \\
1423 \\
594 \\
1208\end{array}$ & $\begin{array}{l}\mathbf{M} \\
\mathbf{M} \\
\mathbf{M} \\
\mathbf{M} \\
\mathbf{M} \\
\mathbf{M} \\
\mathbf{F} \\
\mathbf{M} \\
\mathbf{F}\end{array}$ & $\begin{array}{l}44 \\
41 \\
43 \\
48 \\
40 \\
53 \\
31 \\
35 \\
61\end{array}$ & $\begin{array}{l}\boldsymbol{k} \\
\boldsymbol{k} \\
\boldsymbol{k} \\
\boldsymbol{k} \\
\boldsymbol{k} \\
\boldsymbol{k} \\
\boldsymbol{k} \\
\boldsymbol{k} \\
\boldsymbol{k}\end{array}$ & $\begin{array}{l}- \\
+ \\
+ \\
+ \\
+ \\
+ \\
+ \\
+\end{array}$ & $\begin{array}{r}\overline{1 / 8} \\
\overline{-} \\
\overline{-} \\
\overline{1 / 2} \\
\underline{-}\end{array}$ & $\begin{array}{l}+ \\
+ \\
+ \\
- \\
+ \\
+ \\
+ \\
+ \\
-\end{array}$ & $\begin{array}{c}- \\
- \\
- \\
++ \\
+++ \\
\bar{t} \\
++\end{array}$ & $\begin{array}{c}\text { ND } \\
\text { ND } \\
-\overline{+}+ \\
+++ \\
+++ \\
\text { ND } \\
++++ \\
\text { ND } \\
+++\end{array}$ & $\begin{array}{c}\text { ND } \\
\text { ND } \\
\text { ND } \\
\text { ND } \\
- \\
\overline{N D} \\
\overline{\text { ND }}\end{array}$ \\
\hline $\begin{array}{r}1347 \\
1395 \\
885 \\
1272 \\
701 \\
329\end{array}$ & $\begin{array}{l}\mathbf{F} \\
\mathbf{F} \\
\mathbf{M} \\
\mathbf{F} \\
\mathbf{M} \\
\mathbf{M}\end{array}$ & $\begin{array}{l}46 \\
21 \\
46 \\
58 \\
48 \\
47\end{array}$ & $\begin{array}{l}\boldsymbol{g} \\
\mathbf{g} \\
\mathbf{g} \\
\mathbf{g} \\
\boldsymbol{g} \\
\boldsymbol{g}\end{array}$ & $\begin{array}{l}- \\
+ \\
+ \\
+ \\
+\end{array}$ & $\begin{array}{l}1 / \overline{4} \\
1 / \overline{2} \\
1 / 4 \\
1 / 2\end{array}$ & 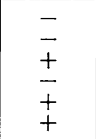 & $\begin{array}{c}++ \\
\overline{+} \\
++ \\
++ \\
-\end{array}$ & $\begin{array}{c}+++ \\
\text { ND } \\
+++ \\
\text { ND } \\
+++\end{array}$ & $\begin{array}{l}\text { ND } \\
\text { ND } \\
\text { ND } \\
\text { ND } \\
\text { ND } \\
\text { ND }\end{array}$ \\
\hline
\end{tabular}

$a=$ tabes dorsalis

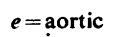
incompetence $f=$ aneurysm $\quad j=$ gumma $b=$ paresis $d=$ aortitis

PPR + Positive in undiluted serum.

PPR $1 / 8$, etc. $=$ Positive in serum diluted 1 in 8 , etc. ND $=$ Not done.

group, the reaction was positive in 32.5 per cent. (at the first test) and 66.6 per cent. (at the second test).

In thirteen patients tested within a short time of starting penicillin treatment and in whom the infection was probably still active, the "luotest" reaction was positive in 50 per cent. (at the second test).

It is concluded that the "luotest" is not helpful in the modern diagnosis, management, or exclusion of syphilis. 
We are indebted to Dr A. Rottmann and the Austrian State Serum Institute, Vienna, for the supply of "luotest" material; to Dr W. Grillmayr for his help with the interpretation of the skin reactions; and to Dr Blair and the Management Committee of Springfield Hospital, Manchester, for permission to examine the patients in their care.

\section{REFERENCES}

Csonka, G. W. (1950). Med. illus., 4, 389.

Grillmayr, W. (1956). J. Indian med. Ass., 27, 351.

Neisser, A. (1911). "Bieträge zur Pathologie und Therapie der Syphilis". Springer, Berlin.

Noguchi, H. (1911). Münch. med. Wschr., 58, 2372.

Rottmann, A. (1946). "Neue Wege in der Diagnostik und Therapie der Lues". Hollinek, Vienna.

\section{Evaluation du "Luotest" dans la syphilis tardive RÉSUMÉ}

Le "Luotest" a été fait dans quarante cas montrant des signes cliniques et sériques de la syphilis, et aussi dans un autre groupe de 39 malades chez lesquels la syphilis pouvait être exclue. En sus des tests "réagine", le P.T.I. a été inclus dans les examens sériques.

La réaction "Luotest" a été positive chez deux malades du groupe non-syphilitique chez lesquels un seul test intradermique avait été fait. Dans le groupe syphilitique la réaction a été positive dans 32,5 pour cent au premier test et 66,6 pour cent au second test.

Chez 13 malades qui ont subi le test très peu de temps après avoir commencé un traitement à la pénicilline, et chez lesquels l'infection était encore probablement active, la réaction "Luotest" a été positive dans $\mathbf{5 0}$ pour cent au second test.

Il a été conclu que le "Luotest" n'est pas une aide dans le diagnostic moderne, le contrôle ou l'exclusion de la syphilis. 